\title{
The Macroeconomic Context of Investments in the Field of Machine Tools in the Czech Republic
}

\author{
- Povolná Lucie, Švarcová Jena
}

\begin{abstract}
The article focuses on the macroeconomic analysis of production, export, import and investment in machine tools in the Czech Republic in the context of the initiative of Industry 4.0. Machine tools (MT) are among traditional industries in the Czech Republic and the industry has an innovative and growth potential. However, the economic crisis may disrupt or modify this trend. The article focuses on the analysis of correlations between GDP growth and production of MT, MT exports and investments in MT in the Czech Republic after the accession to the European Union in 2004 during the economic crisis of 2009 and the post-crisis development until 2014. The results show that production and exports are directly related to fluctuations in GDP and the economic cycle, but domestic investment in machine tools did not show this dependence. It is necessary to capture new trends to increase the competitiveness of the MT industry. The course of recovery of Czech economy after the economic crisis of 2009 indicates signals of qualitative changes in the traditional field of machine tool production. Comparing the years 2013 and 2014, it shows that export MT (SITC 731) fell in 2014, although the total exports from the Czech Republic to Europe and to the world grew significantly.
\end{abstract}

Keywords: investment in machine tools, economic growth, Industry 4.0, export, economic crisis JEL Classification: M10, O31, R11

\section{INTRODUCTION IN TO MACROECONOMIC ANALYSIS}

The Czech Republic's initiative “The industry 4.0" (Korbel, 2015) emphasizes the important innovations coming in mature industries. The article focuses on investments in new machine tools in the Czech economy, depending on the changing economic situation in the country. Machine tools have a very wide application in industry. The Czech Republic is closely associated with production and export of machine tools, which are an important part of current GDP. Engineering is also a major employer, even though in recent years, the technical fields in the Czech Republic have faced a lower interest of students in comparison with the needs of companies (Švarcová and Gabrhel, 2012) (Dobeš and Virglerová, 2016).

Kennedy and Corfee-Morlot (2013) explore the investment implications of moving to low-carbon, climate-resilient infrastructure. These big global trends require new investments in modern machinery, which creates opportunities for Czech engineering companies. The risks are, however, fluctuations in demand caused by the economic crises. The article focuses on the analysis of the period before and after the economic crisis of 2009 in the Czech Republic.

The economy is characterized by continuous short-term and long-term fluctuations. The economic cycles are a complex picture of the processes taking place in the dynamic economic reality (Barakauskaite-Jakubauskiene, 2011). Economic growth can be defined as the growth and devel- 
opment of the productive capacity of the country, which is manifested by increased product. The basic indicator for the results of the economic growth is the gross domestic product (GDP).

Cyclical fluctuations in the economy are strongly influenced by the growth and development of industries. Already Schumpeter (1989) emphasizes in his work that innovation has a very beneficial effect on volatility, and if this process will be of a continuous innovation, progressive innovation raises the possibility of the company to succeed in the market through competitive products. Entrepreneurs through their own abilities and initiatives can create new opportunities for investment and thus to contribute to economic growth (Barakauskaite-Jakubauskiene, 2011). Entrepreneurs are motivated by "profit from innovation." Valenta (2001) states that "profit from innovation" is made up through increased prices set by the market of the product at the beginning of its life cycle, and savings from reduced production costs. Fuchsová and Siviček (2013) described a strong correlation between total investments and patent activity as a source of prospective growth. The Industry 4.0 Initiative (Korbel, 2015) is interested in achieving competitive advantages of the Czech Republic due to profit from innovation.

The recession plays an important role in cyclical fluctuations. From one point of view, the recession works in favor of improving and streamlining production processes. The consequence is the shift of production factors from less productive firms to innovative companies, cleaning market, industrial development and long-term economic growth. Lin and Huang (2012) show that the relocation process is shifting resources towards manufacturers who use new technologies, and they also confirm the hypothesis of Schumpeter (1989) that the economic crisis leads to qualitative changes. A higher propensity to innovate was recorded in the companies exporting abroad (Tavassoli, 2012).

Großler et al. (2015) deals with finding an optimum strategy in order to replace production equipment, which is one of the options taking into account the economic cycle. The economic cycle affects the price of the used equipment under six years more than the price of a new one. Großler et al. (2015) states that the purchase of a new equipment is moving into a period of the economic downturn, when prices stagnate and sales of the used equipment is better achieved in a period of growth when their prices rise. As concluded by Großler (2015), companies can maintain production equipment younger if the applied approach is into account the economic cycle.

\section{FORMULATION OF THE PROBLEM}

Production of machine tools (MT) is important for Czech industry and export - in 2016, there were exported from the Czech Republic to Europe in the field of SITC 731 machine tools in the value of 9,236 billion CZK (CZSO foreign trade statistics database, 2017). This is a traditional branch in the Czech Republic, and machine tools are important for many types of productions. The subject of this research is the interrelationship between economic fluctuations and the results of the industry of machine tools in the period before and after the financial crisis, particularly in the years 2004 - 2014. Theories predict that the economic downturns are a breeding ground for the recovery of fields and a stimulus for the development of new technologies and innovation, which is also supported by the National Initiative The Industry 4.0 (Korbel, 2015). An important question is whether the innovations of recent years are so technologically 
fundamental that gradually lead to a decline in a specific industry, in this case, the decline in traditional metalworking. On October 4, 2016 at the International Engineering Fair in Brno, there was held a day-long conference on 3D printing, which is one of the major innovations that may supplant traditional metalworking in particular cases. Likewise, a trend towards the electric cars will reduce the demand for conventional machine tools.

\subsection{Research questions and hypotheses}

What is the relationship between domestic investment in machine tools (domestic consumption of machine tools) and performance of the whole economy? Is there a correlation between domestic consumption of machine tools (MT) and production of MT, exports of MT and imports of MT?

Hypothesis 1: Investment in machine tools in the Czech economy is directly dependent on the economic cycle.

Hypothesis 2: The production and export of machine tools in the Czech economy are directly dependent on the economic cycle.

Hypothesis 3: The recovery of the Czech economy after the economic crisis of 2009 indicates signals of qualitative changes in the traditional field NACE28 Manufacture of machine tools.

\section{RESEARCH METHOD}

\subsection{The data source}

The data of the Czech Statistical Office (CZSO) of GDP for the Czech economy and GDP for the manufacturing industry (category C, i.e. NACE 10-33) were used in the research and the data from the Report on the Machine Tools Branch in the Czech from the Association of Engineering Technology (AET). Here we were interested in data on the consumption, production, imports and exports of machine tools (MT).

Due to availability, the data of $2004-2014$ were used. This period was chosen deliberately: in 2004, the Czech Republic joined the EU and the single European market, which greatly helped the balance of payments, particularly a positive trade balance and strengthening the export position of the Czech Republic, as well as the entry of foreign investors. In 2009, the Czech Republic showed the effects of the global economic crisis, which in terms of this article may be one of the important impulses for innovation. The research period ended in 2014, because at that time the Czech Statistical Office changed, following the recommendations of EUROSTAT, the GDP calculation methodology (introduction of ESA 2010), which could affect the results of the analyzes. The data are in constant prices, we are working with the year over year (YOY) indices where the value of the last year is $100 \%$.

\subsection{The method of analysis}

The overview with the values of GDP for the manufacturing industry (NACE C to GDP), the CZECH GDP, export MT, import MT, production MT and consumption MT (domestic invest- 
ment in machine tools) was made. These indicators do not include spare parts and accessories.

The consumption of machine tools is the most important of the characteristics, since it reflects the level of investment in machine tools on the territory of the Czech Republic and it is calculated as follows:

Consumption $M T=$ Production $M T+$ Import $M T-$ Export MT.

Year over Year indexes were calculated from the data. The most striking differences were searched in each series by means of variance and standard deviation. These results were also handled graphically. The correlation analysis was used to confirm the hypotheses 1 and 2 .

The export MT is largely oriented towards EU countries (see Tab. 1) and the contracts are concluded in euros. Current prices at current exchange rates are used. However, the euro was relatively volatile during the period (see Fig. 1), therefore, it is necessary to consider the impact of exchange rate movements. Separately it is necessary to see the influence of a controlled weakening of the CZK by CNB conducted from November 2013 until now (the exchange rate commitment at the level of $27 \mathrm{CZK} / \mathrm{EUR})$. It is likely that this monetary stimulus generally resulted in an increase in Czech exports (see Tab. 1). The export MT (SITC 731) had a different course in 2014 - even though the exchange rate has weakened, the export MT (SITC 731) fell in 2014.

Tab. 1 - The export of CR 2004 - 2014 according to territories compared with the export MT. Source: CNB and CZSO (2017)

\begin{tabular}{|c|c|c|c|c|c|c|}
\hline $\begin{array}{l}\text { Czech Export in } \\
\text { mil CZK }\end{array}$ & 2004 & 2005 & 2006 & 2007 & 2008 & 2009 \\
\hline $\begin{array}{l}\text { Czech Export to } \\
\text { World }\end{array}$ & 1432638 & 1716010 & 1932904 & 2160136 & 2138826 & 1911128 \\
\hline $\begin{array}{l}\text { Czech Export to } \\
\text { Evrope }\end{array}$ & 1324325 & 1573115 & 1780209 & 1992640 & 1976100 & 1752565 \\
\hline $\begin{array}{l}\text { Czech Export } \\
\text { SITC } 731\end{array}$ & 7453 & 7156 & 7813 & 9961 & 11352 & 8654 \\
\hline $\begin{array}{l}\% \text { SITC731 in } \\
\text { Export World }\end{array}$ & $0,52 \%$ & $0,42 \%$ & $0,40 \%$ & $0,46 \%$ & $0,53 \%$ & $0,45 \%$ \\
\hline $\begin{array}{l}\% \text { SITC731 in } \\
\text { Export Europe }\end{array}$ & $0,56 \%$ & $0,45 \%$ & $0,44 \%$ & $0,50 \%$ & $0,57 \%$ & $0,49 \%$ \\
\hline $\begin{array}{l}\text { Czech Export in } \\
\text { mil CZK }\end{array}$ & 2010 & 2011 & 2012 & 2013 & 2014 & \\
\hline $\begin{array}{l}\text { Czech Export to } \\
\text { World }\end{array}$ & 2194048 & 2437596 & 2624117 & 2681419 & 3039718 & \\
\hline $\begin{array}{l}\text { Czech Export to } \\
\text { Evrope }\end{array}$ & 2005694 & 2223778 & 2363248 & 2421557 & 2748071 & \\
\hline $\begin{array}{l}\text { Czech Export } \\
\text { SITC } 731\end{array}$ & 6835 & 8861 & 10480 & 10580 & 10197 & \\
\hline
\end{tabular}




\begin{tabular}{|l|c|c|c|c|c|}
\hline $\begin{array}{l}\% \text { SITC731 in } \\
\text { Export World }\end{array}$ & $0,31 \%$ & $0,36 \%$ & $0,40 \%$ & $0,39 \%$ & $0,34 \%$ \\
\hline $\begin{array}{l}\% \text { SITC731 in } \\
\text { Export Europe }\end{array}$ & $0,34 \%$ & $0,40 \%$ & $0,44 \%$ & $0,44 \%$ & $0,37 \%$ \\
\hline
\end{tabular}

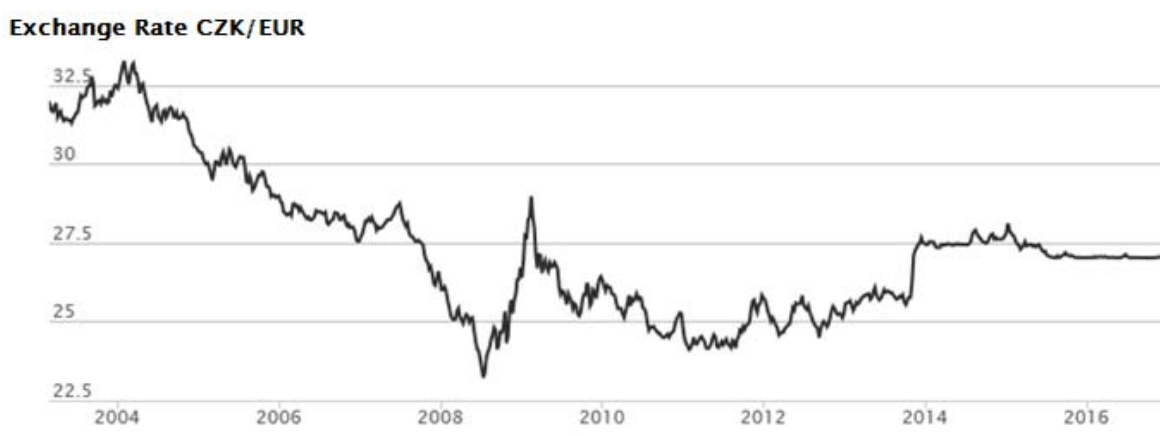

Fig. 1 - The CZK exchange rate to euro from 2004 to 2014. Source: CNB, (2017)

\section{PROBLEM SOLVING AND RESULTS}

Figure 2, which includes the value of the annual change in GDP (in purchasing prices) and GDP for industrial production NACE C, shows a significant difference between GDP growth for the whole economy and GDP development for industrial production. The industrial production demonstrated larger fluctuations than the entire economy. The standard deviation of the annual change in GDP is $\sigma=3.27$ and GDP per NACE C is $\sigma=8.39$ in the period. An indicator of the industrial production growth started to decelerate in 2007, the first signals coming from the economic crisis experienced earlier than other sectors of the economy. We can therefore talk about a certain signal function of this indicator.

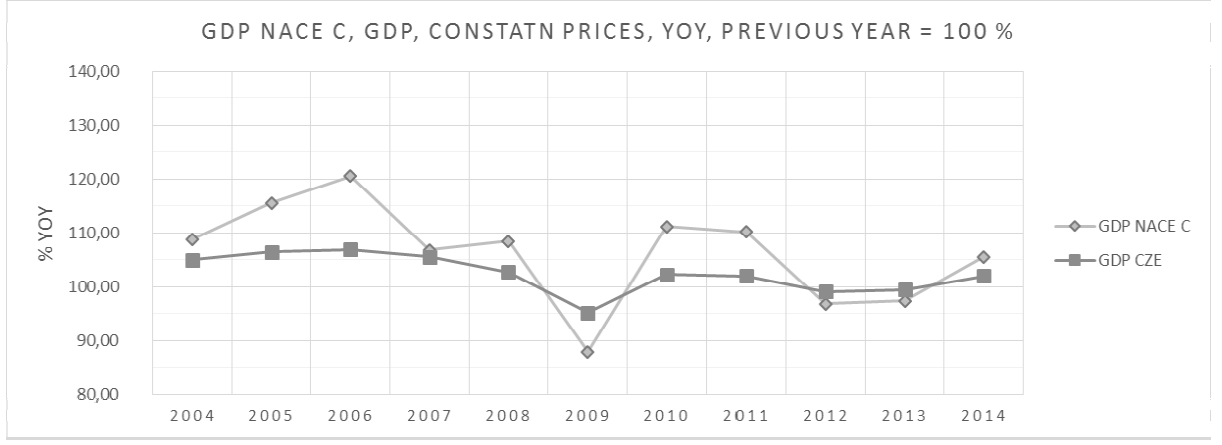

Fig. 2 - Czech GDP and GDP industrial production (NACE C) 2004-2014, constant prices. Source: CZSO (2017). 
The overview of the development of all four performance indicators in the field of machine tools shows that they all respond to the economic development but each in different manner (Fig. 3). The closest to the economic development is the development of exports MT $(\sigma=14.09)$, production MT $(\sigma=18.71)$. The most remarkable fluctuations are captured by import $(\sigma=28.71)$ and especially consumption MT where $\sigma=68.03$. In almost all years, this manner of order is observed in downturns and upturns as well.

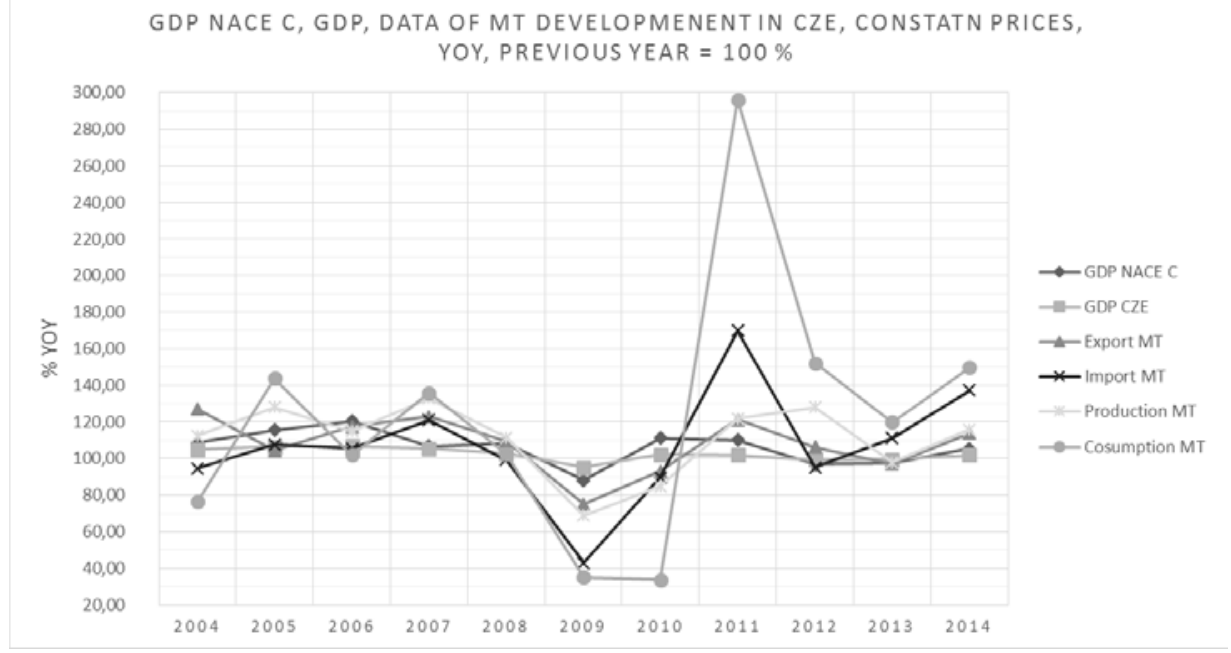

Fig. 3 - GDP in the Czech Republic, Czech industrial production, development of indicators in Machine Tools Branch in the Caech Republic from 2004 to 2014, constant prices. Source: CZSO 2016; EAT: Reports on the state of Machine Tools Branch in the Crech Republic (2017).

The variability of indicators in terms of years was highest in 2011. The most significant change occurred in the consumption MT, which has increased year on year to $296.29 \%$ of the value of the previous year. A ratio indicator slightly distorts the situation because the fall in consumption in 2009 was so deep that we compare very low numbers. The cause of the significant decrease in consumption is weakening of the economies of the countries, where the Czech Republic exports. Due to the expectation of reduced investments, an appetite to invest decreased in all production facilities. Some entrepreneurs very slowly accepted the fact that there was a need to start producing in a different way and they did not achieve the sufficient competitiveness at the beginning. The idea of the indicators can be completed by the following Figure 4 in CZK (EUR) of the Association of Engineering Technology (EAT), which also includes the forming machines. 


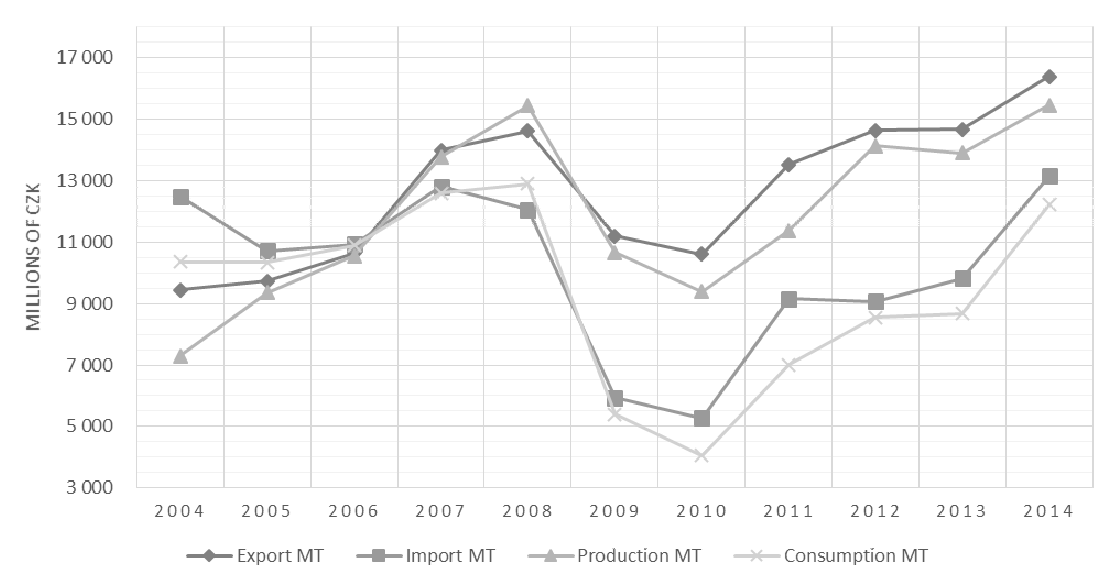

Fig. 4 - The development of indicators in Macbine Tools Branch in the Czech Republic from 2004 to 2014 in million CZK constant prices. Source: Association of Engineering Technology: Reports on the state of Machine Tools Branch in the Czech Republic (2017).

It is obvious that in absolute figures the jump in 2011 is rebounding from bottom. Return to the pre-crisis numbers occurred in 2014. There is an interesting situation for exports. Fig. 4 shows that the export of MT exceeds their domestic production in some years. The disproportion is so significant that it cannot be considered a statistical error. A partial explanation may be reexported import by Czech retail channels.

The hypothesis 1 was tested by means of correlation. The correlation coefficient is $r=0.14970$; $r \leq 0.3$. A direct relationship of the two selected variables has not been proved, H1 cannot be proved.

More complex changes in consumption of machine tools and Czech GDP in the years 2010 2013 can be explained by the significant impact of the economic situation of the countries with which the Czech economy is closely tied, and a different course of transformation in various sectors of Czech industry.

The growth rate of consumption MT was compared with the growth rate of the country's GDP (Fig. 5). Then, the growth rate of consumption MT was compared with a coefficient of GDP growth in NACE C (Fig. 6). The development trend of industrial production corresponds to the development trend of the country's GDP. Differences between years are not significant. 


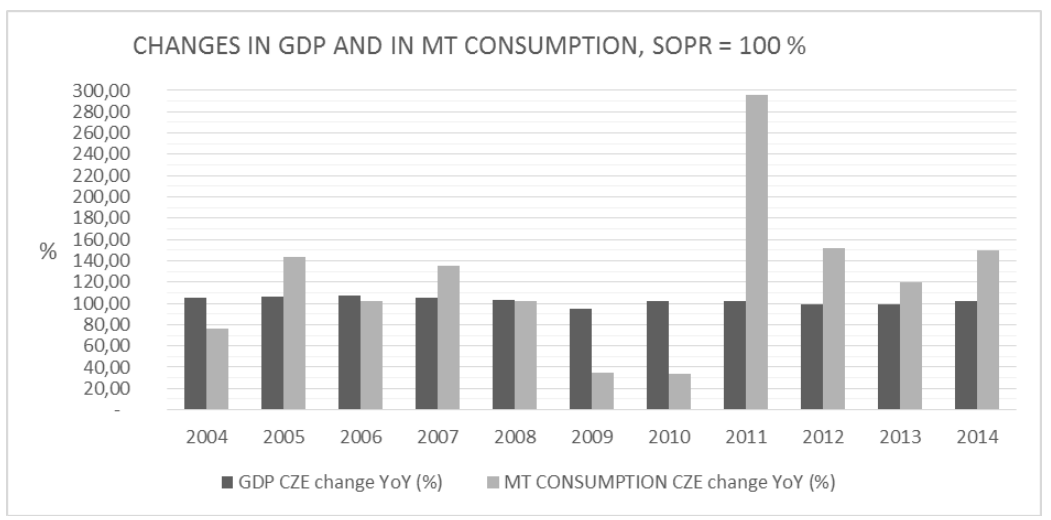

Fig. 5 - Annual changes in the country's GDP and consumption MT in the Czech Republic from 2004 to 2014, constant prices. Source: CZSO, (2017). Association of Engineering Technology: Reports on the state of Machine Tools Branch in the Crech Republic 2007 - 2014.

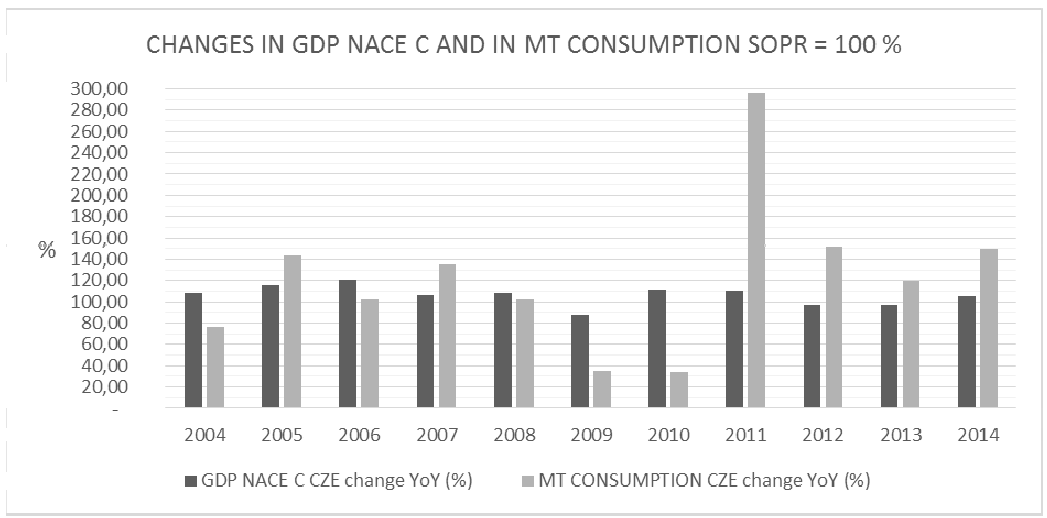

Fig. 6 - Annual changes in industrial production GDP NACE C and consumption MT in the Czech Republic from 2004 to 2014, constant prices. Source: CZSO, (2017). Association of Engineering Technology: Reports on the state of Machine Tools Branch in the Czech Republic 2007 - 2014.

The hypothesis 2 examines the relationship between exports and production of machine tools with GDP growth (Fig.7). The correlation coefficient for GDP and Export MT r $=0.72702$ and for GDP and production of MT is $r=0.63950$; in both cases $\mathrm{R} \geq 0.6$, and $\mathrm{p}$-value $\leq 0.05$.

The hypothesis 2, which says that the production and export of machine tools in the Czech economy are directly dependent on the economic cycle, can be confirmed.

Engineering firms started implementing new technologies with regard to energy consumption and environment after the economic crisis in 2010 and 2011. Additionally, budget cuts played an important role and a general decline in investment in this period. (Association of Engineering Technology: Reports on the state of Machine Tools Branch in the Czech Republic 2011) 


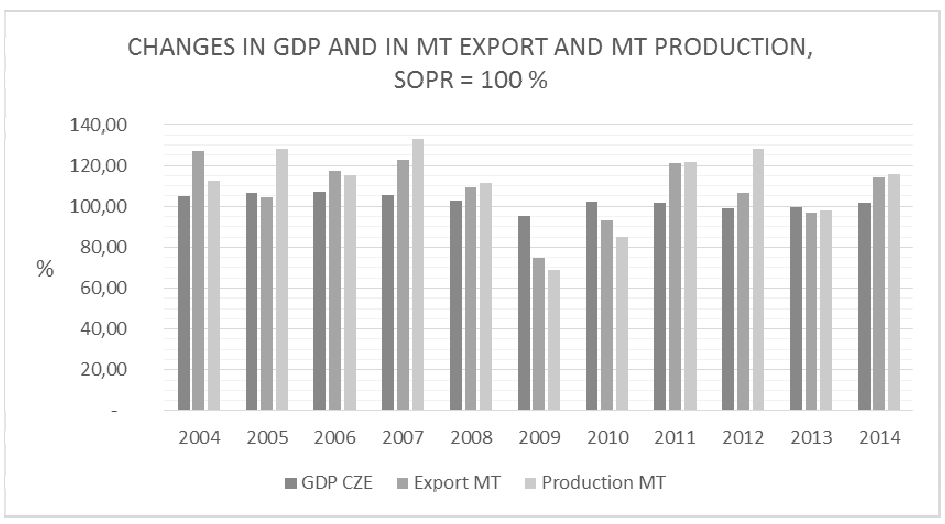

Fig. 7 - Annual changes in the country's GDP and exports and production of machine tools in the Crech Republic from 2004 to 2014, constant prices. Source: CZSO, (2017). Association of Engineering Technology: Reports on the state of Machine Tools Branch in the Czech Republic 2007 - 2014.

The hypothesis 3 argues that the course of recovery of Czech economy after the economic crisis of 2009-2010 indicates signals of qualitative changes in the traditional field NACE28 Manufacture of machine tools. The hypothesis 3 is the most complex because it cannot be proved only by year changes in indicators (Fig. 8). This concept does not provide sufficient information.

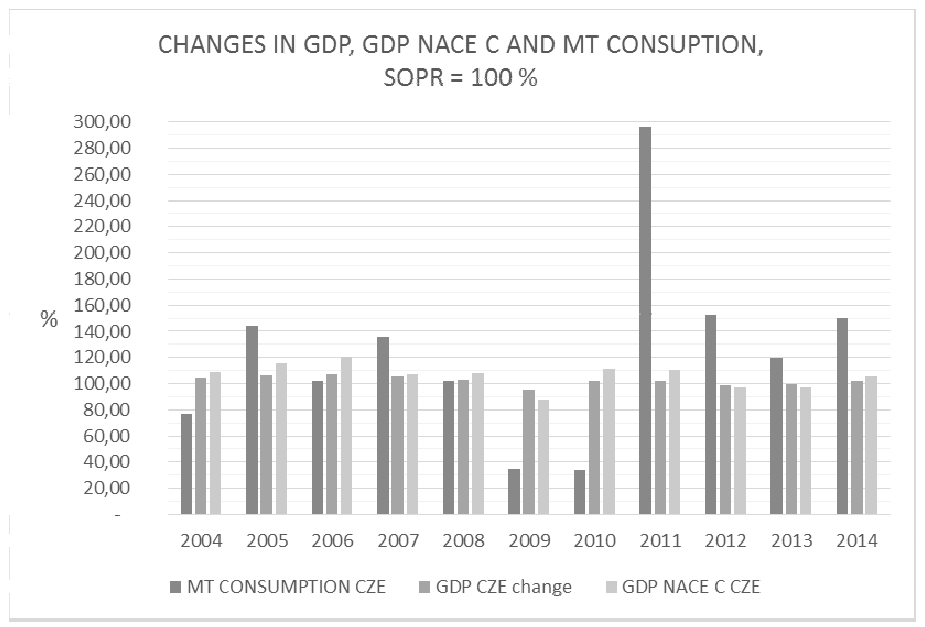

Fig. 8 - Annual changes in the country's GDP, industrial production and consumption MT in the Crech Republic from 2004 to 2014, constant prices. Source: CZSO, (2017). Association of Engineering Technology: Reports on the state of Machine Tools Branch in the Czech Republic 2007 - 2014.

However, more interesting is the share of consumption MT in the GDP of the Czech Republic and the GDP NACE C Czech Republic (Fig. 9). 


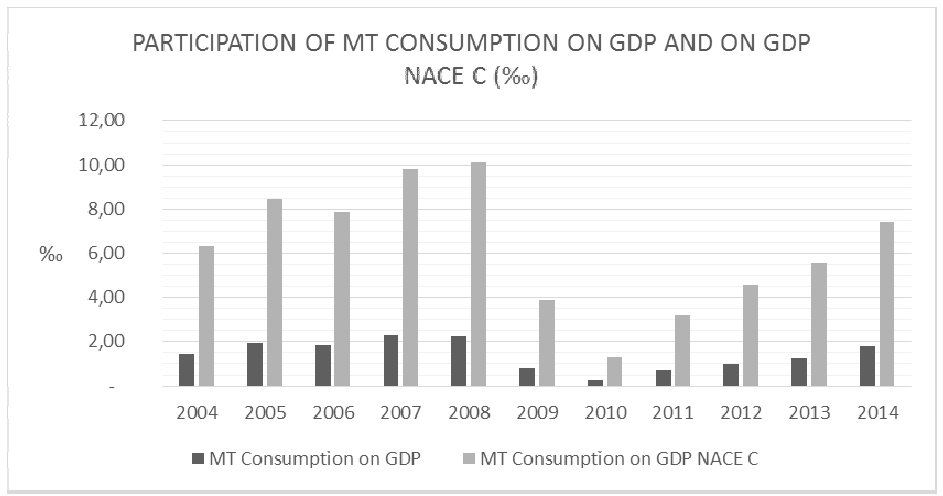

Fig. 9 - Share of consumption of machine tools in creation of the country's GDP and GDP NACE C in the Czech Republic from 2004 to 2014, constant prices. Source: CZSO, (2017). Association of Engineering Technology: Reports on the state of Machine Tools Branch in the Czech Republic 2007 - 2014.

The share of consumption MT in GDP and GDP CR NACE C increases, depending on how the economy revived after the crisis and how the government provided subsidies for the acquisition of new production equipment. The pre-crisis development of the share of consumption MT in the expenditure in industry exceeded the value of post-crisis development. It may be a signal for qualitative changes in the field of machine tools. One of the other quantitative signals can be development of the export MT in Table 1 (SITC 731) comparing the years 2013 and 2014, where it is evident that the export MT behaves differently from total exports. The export MT decreased in 2014, although the total exports from the Czech Republic to Europe and to the world grew significantly.

\section{DISCUSSION AND CONCLUSIONS}

The article addresses important issues of development of Czech engineering after the accession to the EU. The descriptive statistics show that the industry (NACE C) and engineering industry as part of it is an important driver of Czech economy (Fig. 2-8). The article focuses on the analysis of past developments and draws possible future changes.

Discussion of the use of data and methodology: paper uses the calculation of GDP according to the Czech Statistical Office in ESA 2010. Dunn stated that GDP measured by the new method in the Czech Republic increased by $4.1 \%$ for 2010 than under the old methodology (Dunn et al., $2014,12)$. Dunn also analyzes the impact of NACE - revisions in group B, C, D and E reached 5.5 percent in the Czech Republic in the reference year 2010 (Dunn et al, 2014, 15). If, therefore, the authors carried out calculations according to the old methodology, there would be different results.

Hypothesis 1: The investments in machine tools in Czech economy are directly dependent on the economic cycle. The hypothesis was tested by means of correlation. The correlation coefficient is $r=0.14970 ; r \leq 0.3$. A direct relationship of the two selected variables in the period 2004 to 
2014 has not been demonstrated. That may have a lot of causes - Figure 8 shows that the growth rate of domestic consumption MT in 2011-2014 was significantly higher than the GDP growth. The growth in domestic investment in machinery thus outstrips the growth in GDP and the proportion of the investment is covered by a faster importing, particularly in 2011 (see Figure 4). Interestingly, the controlled weakening of CZK in 2014 appeared to have no slowdown in import of machinery, import surprisingly grew (see Figure 4).

Hypothesis 2: The production and exports of machine tools in Czech economy are directly dependent on the economic cycle. The correlation coefficient for GDP and Export MT r $=0.72702$ and for GDP and production of MT is $r=0.63950 ; \mathrm{R} \geq 0.6$, and $\mathrm{p}$-value $\leq 0.05$. The hypothesis can be confirmed in the period 2004 to 2014. The export performance of Czech engineering is a significant part of GDP, the question is whether export is conditioned by the GDP growth or GDP growth is dependent on the export growth. An interrelation can be expected. The relationship of export and import is also interesting - Figure 4 shows that the import MT in 2014 grew faster than production and export regardless of the worsened exchange rate for the import. Another scenario is the possibility of development of qualitative changes that are examined in Hypothesis 3.

Hypothesis 3: The course of recovery of Czech economy after the economic crisis of 2009 indicates signals of qualitative changes in the traditional field NACE28 Manufacture of machine tools. One of the quantitative signals can be the development of export MT in Table 1 (SITC 731) comparing the years 2013 and 2014, where it is evident that the export MT behaves differently from the total exports. The export MT in 2014 decreased, although the total exports from the Czech Republic to Europe and to the world grew significantly.

Discussion on the research results: the results were influenced by the choice of a new methodology for calculating GDP, to the extent of percent. The new methodology ESA 2010 calculates results of science and research differently. Dunn states that the impact of methodological changes in R \& D was 1.2\% of GDP in 2010 in the Czech Republic (Dunn et al, 2014, 12). This shows that $\mathrm{R} \& \mathrm{D}$ is very important for further development of engineering in the country. Industry should be advised to focus on products with a high added value thanks to the results of science and research. A very important one is also the exchange rate policy of the central bank. In 2013, the CNB launched a controlled weakening of the Czech crown against the euro. Unfortunately, this monetary policy ends in 2017. Companies should seek additional protection mechanisms to increase efficiency. Better performance in $\mathrm{R} \& \mathrm{D}$ and high-quality patent protection can be a way to higher performance in a period of strong crown.

During the reporting period, years 2004 - 2014, the Czech economy has underwent fundamental changes. The global financial crisis that gripped the world in 2008 caused a turnover in approach of Czech producers to the market with the objective to become truly competitive. Many productions went through the consolidation or reorganization in order to achieve lower prices while maintaining or increasing the quality of the product, and manufacturers began to listen more to the customer requirements.

In the paper, the performance indicators of the branch of machine tools in the Czech Republic in relation to the economic cycle were examined. It has been demonstrated that the investment 
in machine tools in the Czech economy is primarily the leading indicator of development of the economic cycle. There has also been a significant influence of governmental support for the production fields. The export and production of machine tools are dependent on the economic cycle.

The relationship of investment in the machine tools (consumption MT) and GDP is mutual - development of the GDP induces new investments, but also investments in machine tools accelerate economic development. A simple quantitative aspect of investment, however, does not guarantee the competitiveness of the country. Innovation is an important dimension of investment, which does not necessarily remain within the industry only. The results for the tested period may indicate a qualitative change coming with technological development declared by the initiative Industry 4.0. Finally, the machine tools consumption (investments) has an influence on the development of economy. The way producers invest in production facilities, it is reflected in all industries performance. New equipment and new technology is the promise of a higher productivity and greater competitiveness of the final products.

\section{References}

1. Barakauskaité-Jakubauskiené, N. (2011). Logistic Capital Management Theories and Theoretical Aspects of Economic Growth Cycle. Economics \& Sociology, 4(1), 33-45. doi:10.14254/2071-789x.2011/4-1/4.

2. Databáze zahraničního obchodu. (2017). Český statistický úřad. Retrieved from: http://apl. czso.cz/pll/stazo/STAZO.STAZO.

3. Dobeš, K., \& Virglerová, Z. (2016). A Statistical Analysis of Students' Interest in Financial Professions on the Czech Labor Market (2016). The International Journal of Interdisciplinary Educational Studies, 11(2), 27-36. doi:10.18848/2327-011x/cgp/v11i02/27-36.

4. Dunn, M., Akritidis L. \& Biedma L. (2014). The impact of ESA 2010 on key indicators of the national accounts in Europe. Eurostat Review on National Accounts and Macroeconomic Indicators: Special Issue on the Implementation of the European System of Accounts (ESA 2010). Luxembourg: Publications Office of the European Union, 2014(2), 8-27.

5. Export ČR 2004 až 2014 dle teritorií. (2017). Česká národní banka Retrieved from: http:// www.cnb.cz/analytics.

6. Export MT 2004 až 2014 dle teritorií. (2017). Český statistický úřad Retrieved from: http://apl.czso.cz/pll/stazo/STAZO.STAZO.

7. Fuchsová, E., \& Siviček, T. (2013). FDI as a Source of Patent Activity. Proceedings of the 11th International Conference Liberec Economic Forum. 146-155. Liberec: TU Liberec.

8. Größler, A., Bivona, E., \& Li, F. (2015). Evaluation of asset replacement strategies considering economic cycles: lessons from the machinery rental business. International Journal of Modelling in Operations Management, 5(1), 52-71. doi: 10.1504/IJMOM.2015.069241.

9. Kennedy, C., \& Corfee-Morlot, J. (2013). Past performance and future needs for low carbon climate resilient infrastructure-An investment perspective. Energy Policy, 59, 773-783. doi:10.1016/j.enpol.2013.04.031. 
10. Korbel, P. (2017). Průmyslová revoluce 4.0: Za 10 let se továrny budou řídit samy a produktivita vzroste o třetinu. Hospodářské noviny. Retrieved from: http://byznys. ihned.cz/c1-64009970-prumyslova-revoluce-4-0-za-10-let-se-tovarny-budou-ridit-samy-aproduktivita-vzroste-o-tretinu.

11. Lin, Y. C., \& Huang, T. H. (2012). Creative destruction over the business cycle: a stochastic frontier analysis. Journal of Productivity Analysis, 38(3), 285-302. doi: 10.1007/s11123-0120273-3.

12. Schumpeter, J. A., \& Fels, R. (1989). Business cycles: A theoretical, historical and statistical analysis of the capitalist process. Philadelphia, Pa: Porcupine Press.

13. Švarcová, J., \& Gabrhel, V. (2012). Vzdělanostní aspirace a vzdělanostní mobilita studentů středních škol v České republice. E+ M Ekonomie a Management. 15(2), 1-14.

14. Tavassoli, S. (2015). Innovation determinants over industry life cycle. Technological Forecasting and Social Change, 91, 18-32. doi: 10.1016/j.techfore.2013.12.027

15. Valenta, F. (2001). Inovace v manažerské praxi. Praha, Velryba.

16. Vývoj kurzu CZK k EUR 2004-2014. (2017). Česká národní banka. Retrieved from: http://www.cnb.cz/cs/financni_trhy/devizovy_trh/kurzy_devizoveho_trhu/grafy_form. jsp?c=EUR.

17. Zdroje hrubého domácího produktu, Hrubý domácí produkt - Časové raady ukazatelů čtvrtletních účtů. (2017). Český statistický úřad. Retrieved from: https://www.czso.cz/csu/ czso/hdp_cr.

18. Zpráva o stavu oboru obráběcích a tvářecích strojů v České republice 2007-2014. (2017). Svaz strojírenské technologie. Retrieved from: http://www.sst.cz/index.php/cs/statistika/ ceska-republika-rocni.

\section{Contact information}

Ing. Lucie Povolná

Tomas Bata University in Zlín, Faculty of Management and Economics

Mostni 5139, 76001 Zlin, Czech Republic

E-mail:lucie.povolna@ujep.cz.

doc. Ing. Jena Švarcová, Ph.D.

Tomas Bata University in Zlin, Faculty of Management and Economics

Mostni 5139, 76001 Zlin, Czech Republic

E-mail:svarcova@fame.utb.cz. 